\title{
International Law on the Threshold of the $2 \mathrm{I}^{\text {st }}$ Century
}

\author{
Alejandro J. RODRíGuez CARRIÓN*
}

\section{(A) THE SUBJECTS OF INTERNATIONAL LAW}

International law emerged as a legal system that exclusively regulated the relations between states, and states were its only accepted subjects. Its very name - international law - which was first formally used in 1780 , points to an identification of states based on the concept of the nation-state. Other than states, no other entities were legally recognized. Even when the first forerunners of international organizations - the river commissions and administrative unions - emerged over the course of the $19^{\text {th }}$ century, the need to consider their legal status, and the impossibility of considering that anything other than states could be regulated, led to the use of the legal fiction of treating them "as if they were states", a recourse that made it possible to solve problems in practice without the need for expansions that would break the theoretical mould.

Today, there is no longer any debate: whilst states are certainly the primary subject of international law, its logical prius in the understanding of the international system, new sociological realities have led - not always peacefully - to the legal acceptance of rights and obligations of emerging subjects of international law.

\section{(1) The alleged crisis of state sovereignty}

Internationalists have not generally been characterized by the excessive legal formalism of our analyses of state sovereignty. Hence, although the international legal system proclaimed the principle of sovereign equality of states, this principle was to be understood more as an aspiration for the establishment of an orderly international society than as a proclamation of an existing reality. Indeed, it is already a classic in internationalist scholarship to highlight how the international system itself discriminates between states depending on their status in the international pecking order. Some of this discrimination, as appalling as it might seem, is simply the attestation of an unequal distribution of political power in international society. For instance, in establishing the voting procedure for the adoption of decisions by the organization's Security Council, Article 27 of the Charter of the United Nations enshrines the right to veto of the five great powers to emerge from World War II. Correlatively, it is noted, it is not a question of granting them privileges over the other members of international society, but of attributing to them a special responsibility in the maintenance of international peace and security. As a result, the accusations levied against the great powers for the existing disorder in international society should not be regarded as demagogic, but rather the logical consequence of the fact that it is they who are vested

* Former Professor of Public International Law at the University of Málaga. This contribution is part of his inaugural lecture of the $1999^{-2000}$ academic course. Translated by Kari Friedensen, with special funds received from the AEPDIRI. 
with these special powers precisely to avoid falling prey to the perverse paradox of privatizing gains whilst socializing losses.

However, international legal norms also establish rules of positive discrimination for states, in light of their disadvantaged positions on the international socio-economic ladder. Thus, unequal levels of development give rise to special obligations for the best positioned and theoretical net benefits for the worst positioned in the struggle for economic development. Indeed, by the late I96os, it was a commonplace to refer to the emergence of a social international law as opposed to the classical conceptions of liberal international law that had existed to date, akin to the construction in modern states of a social legal system to correct the inequalities that liberal conceptions had produced. For example, development strategies established the obligation for developed states to allocate $0.7 \%$ of their gross domestic product to meeting the needs of developing states; likewise, various, theoretically more advantageous obligations are established for states in geographically disadvantaged situations under the current law of the sea.

The drama in international law stems from the fact that, whilst the rules enshrining political discrimination are restrictive and binding on all members of international society, those establishing positive discrimination mechanisms are programmatic, soft-law, or prematurely established rules, whose legal effects are non-binding and which instead have a recommendatory value for states. The states have the final say on the possibility, advisability, or interest of complying with what these rules urge them to do, without there generally being any legal consequences for non-compliance. Furthermore, whilst in domestic societies the need to set limits on the welfare state is still open to debate, with sometimes dramatic consequences despite the relative internal cohesion of such societies, at the international level the consequences of the dominant ideology have outrageously perverse effects due to the lack of cohesion of international society as a whole. In other words, although in the ig6os the emergence of the first rules of this social international law was met with hope, by the ig8os and, more starkly, in the decade now ending and surely the one to come, we are witnessing the re-emergence of a liberal international law, with incalculable consequences given the already unacceptable levels of inequality found in international society at the turn of the $2 \mathrm{I}^{\mathrm{st}}$ century.

Somewhat disingenuously, today the debate has begun to focus on an issue that, although undeniably important, may serve to camouflage the underlying problems: state sovereignty, it is claimed, is a model for building international society that no longer has the necessary means to achieve the goals it was created for. Sovereignty is blamed for much of the dissatisfaction with the current international order: the scant institutionalization of international society and the excessive atomization of political power amongst sovereign states are the explanatory causes of the distortions of international society. Hence, the proliferation of parties proposing its abolition or, at least, its dramatic limitation, given that state sovereignty is a serious impediment to the rational organization of international society. Furthermore, sovereignty is presented as a relic that conflicts with the new emerging realities of an international society in increasingly close interaction. Intensifying international relations, growing cross-border solidarity, and the inability of states to continue fulfilling the objectives for which state sovereignty was originally designed have even led some to assert that states are an abstraction and sovereignty an incongruity, a bulwark that works against the construction of a more orderly and just world. 
Referring to sovereignty, someone once wrote: "After a long time, these ideas are no longer indisputable. These stout pillars on which the edifice of international law has, to date, rested, giving the appearance of foolproof solidity, have begun to wobble. Under the continuous pressures of life, they threaten ruin. But abundant and rich materials have already been accumulated that enable the reconstruction of international law on new bases." These words are not new. They were penned by Politis in I925. To support his position, he cited examples of international practice. The international regulation of rivers did not allow the division of powers amongst states on a territorial basis; the diplomatic protection of a state's nationals abroad by the state itself established a sort of limitation or subordination that the territorial sovereign had to accept; the minority protection regime, so dear to President Wilson and enshrined in the theory and practice of the League of Nations, was a new limit on the territorialist conceptions of sovereignty; with its patient construction of an international labour code, the Geneva-based International Labour Organization likewise signalled the gradual decline of sovereignty.

Whilst these assertions, however bold, could already be made in I925, today we could advance down this path on surer footing. Any attempt to build an international order will certainly involve some limitation of state sovereignty; the question is whether the construction of international society is possible if the concept of state sovereignty does not persist. In my view, it is worth taking a moment to consider whether, at the threshold of the $2 \mathrm{I}^{\mathrm{st}}$ century, there are sufficient factors to confirm the critical diagnosis of sovereignty. Furthermore, it is necessary to determine whether these factors are definitive, in the sense of decisive, or, on the contrary, could point to contradictory conclusions.

In 1952 , Ramiro Rico wrote, "It is easy to see that, when the West starts speaking about sovereignty, it is to apply to human powers attributes previously reserved for God. It is likewise easy to see how each predicate of sovereignty is intended to be an exact replica of the attributes of God." He had previously written that "because of this transposition of politics and religion, sovereignty, the sovereign, although it is included in political theory, is less a topic of that theory than a subject of theology". The discussion of sovereignty thus becomes a meta-rational question, an affective, belief-related or ideological element, but we must try to move beyond the narrow bounds of these confines. A strictly functionalist analysis shows that, in an increasingly interdependent world, in which no state, not even the most powerful, can achieve autarky, state sovereignty is, to borrow an image formulated by Mao and imported by Chaumant, a paper tiger: cooperation is essential and subordination, in Reuter's classical scheme, is often necessary.

States are becoming more and more aware that achieving the objectives that drove their establishment is no longer so possible for them to do: in the contemporary world, to the extent that states are being debated at all, it is because of their growing proven ineffectiveness in meeting the social demands of their component groups. Other social actors are gradually starting to meet the demands whose fulfilment was previously attributed exclusively to the state. This peaceful dismantling of the state can be seen on at least three levels.

First, governmental international organizations, set up by state governments as an appropriate framework for solving problems that they cannot manage alone, are playing a growing role. The world of international organizations is certainly complex enough to warrant a quick outline, however impressionistic, of their political importance. Whilst organizations can differ in terms of the scope of their composition and vary considerably in terms of the generality or specificity of 
their objectives, they are all endowed, to a greater or lesser extent, with a certain decision-making capability. Consequently, although sometimes they are limited to trying to influence states' behaviour politically, other times their decisions are final and binding on their member states. Not only are international organizations capable of solving problems that states cannot tackle individually, they also often establish goals that would not be feasible for states alone. Thus, international organizations are a functional attack on state sovereignty, by means of elevation.

This situation is particularly clear in the case of international integration organizations, such as those that make up the European Union. In this case, these organizations' decision-making capability, along with their real ability to achieve policies impossible for individual states, leads to a transfer of loyalties from the state to the international organizations. The outcome itself need not pose a threat to the state as such, unless the transfer is accompanied by state decentralization procedures, in which case state nationalism can easily be replaced by nationalisms of a more limited scope, leading to what has come to be called localist or parochial nationalisms.

Second, the political limitations of both states and international organizations, rigidly linked to the achievement of their goals, have led to the increasing emergence of non-governmental international organizations, non-profit-making associations of private individuals that engage in transnational activities and highlight people's dissatisfaction with the failure of states and governmental international organizations to achieve the goals for which each association was created. Although these organizations lack international legal personality, nobody disputes the progressive importance they have acquired. For the purposes of the present analysis, the most important thing is to note that peoples' increasingly international actions - which cannot be constrained by strict political borders - entail a sort of transfer of loyalties from states to nongovernmental organizations, to the extent that, in some cases, the state comes to be perceived as an obstacle to achieving the objectives of the associated individuals. At the same time, states, aware of this phenomenon, make considerable efforts to neutralize these organizations' actions or, at least, make them consistent with state objectives.

Third, and contrary to the old Marxist theses whereby the expansion of the international economy would end up triggering inter-imperialist wars, the concentration and centralization of capital has led to an unprecedented growth of transnational companies, which have set themselves up in the most modern form, albeit different from the old states, able to make decisions and impose policies that do not respect state policy, whilst at the same time emerging as a powerful rival of the state subject.

If these factors have any foundation, it would need to be concluded - as indeed it frequently is - that, in light of international law, sovereignty needs to be reformulated. Nobody can reasonably claim that such a fragile state should legally remain the primary subject of international law, the exclusive international lawmaker, and the party responsible for enforcing international rules. It is impossible to conceive of an international regulation of human rights, the configuration of the right of self-determination of peoples, even beyond the colonial context, or the establishment of rules to regulate an indivisible environment that knows no state borders without the establishment of rules limiting state sovereignty. Faced with these premises, any opposition to redefining sovereignty will be regarded as reactionary, contrary to social dynamics.

However, it should be noted that it may not be state sovereignty as a general concept that is ultimately being challenged, but rather certain forms by which sovereignty is manifested. If, as we 
have seen, the way that states have been classified by international law and reality entails the attribution of unequal rights and obligations, the consequence of the diversity of manifestations of sovereignty would be the consideration that not all states are sovereign equals, but rather that the affirmation of their sovereign powers is related to their ability to perform their functions to achieve objectives internationally defined as essential. In other words, it is not a question of saying, for example, that a great power no longer has the same sovereign rights it once enjoyed, and that the same is true of a micro-state, but rather that the exercise of sovereign powers is only legally acceptable when it is done in pursuit of internationally endorsed purposes and objectives.

This gives rise to extremely delicate questions: if the purposes and objectives are established by the community of states as a whole, then there would be nothing to object to in such a reformulation of sovereignty, except the fear that a limited number of states, well positioned on the social scale, would not allow redefinitions that would interfere with their interests. However, what if it is actually a small number of states - precisely those best positioned on the international stage - that are arrogating to themselves the right to establish the aforementioned purposes and objectives to which the performance of each state's sovereign powers must be subject? In that case, what would be being challenged is the alleged sovereignty of a large number of states that are states in formal name only, not that of states with actual power to act internationally.

From this perspective, a forceful defence of a classical understanding of sovereignty would make sense: any failure to do so would mean affirming the right of a few states to make the rules of the game by which all states must play and even the right to ensure that those rules are enforced. In other words, we would be witnessing the resurgence of two $19^{\text {th }}$-century ideas that are today entirely unacceptable: first, the establishment of a directory of powers with general interests that, like the old Concert of Europe that grew out of the Conference of Vienna in I8I5, had the power to judge and enforce the level of compliance with the established objectives; and, second, the notion that this same group of states would define the objectives to be met at any given time, as well as the means needed to achieve them. From there, the return to the distinction between civilized, semi-civilized, and barbarian states would be just a step away and, with it, the direct rejection of any challenge to a sovereignty that, in reality, is but a discreet formula for dressing up an old idea in new clothes. That this is how things are turning out to be is quite different from claiming that it is how they should be.

\section{(2) The unquestionable strength of international organizations}

Whenever, in the drafting of an international regulatory text, the question of stating whether international organizations have international legal personality and capacity arises, states usually refrain from making general pronouncements. Instead, they make it dependent on the terms of the individual organization's constitutive treaty or, where there is no choice but to make exceptional statements in this regard, make sure to note that it does not prejudge the question of the international personality of international organizations in general. It is not a matter of categorically defending a privileged position that has come under threat but perhaps something much simpler: ultimately, a state feels safer, more equal, arguing with another state, no matter how superior that state may actually be, than with a conglomerate of states set up as an international organization whose potential can be overwhelming. 
Thus, from a strictly legal perspective, it is impossible to say whether international organizations have international legal personality in general. And yet it would be pointless to dispute their political or social importance. No one can fail to see that $20^{\text {th }}$-century international relations have stood out, amongst other things, for the irresistible process of creating international organizations and for the capacity of these organizations to decide on the most diverse aspects of international relations, as well as in the sphere of states' domestic policies. No state, no matter how powerful, can feel immune to these organizations' capacity to influence and even make decisions.

In the international law of the last few decades, this fact has been regarded as an irrefutable element for the understanding of international society. From the legal point of view, interest in the debate over the possible international legal personality of international organizations has waned. The rivers of ink spilt at the time regarding the advisory opinion of the International Court of Justice in the Reparation for Injuries Suffered in the Service of the United Nations case (1949), affirming the legal personality of the United Nations, have - after a calculated discussion of the phenomenon of international personality in general and in relation to organizations in particular - become a commonplace that the literature simply reiterates, virtually without debate, as the International Court of Justice itself has done on other occasions, such as in its advisory opinion in the Interpretation of the Agreement of 25 March 1951 between the WHO and Egypt case (1980).

But the Court's construction of case law has not been limited to affirming these organizations' legal personality. In its advisory opinion in the Legality of the Use by a State of Nuclear Weapons in Armed Conflict case (1996), the Court considered that international organizations "are subjects of international law which do not, unlike states, possess a general competence. International organizations are governed by the 'principle of speciality,' that is to say, they are invested by the States which create them with powers, the limits of which are a function of the common interests whose promotion those States entrust to them." However, it rounded out its reasoning stating that "[t]he powers conferred on international organizations are normally the subject of an express statement in their constituent instruments. Nevertheless, the necessities of international life may point to the need for organizations, in order to achieve their objectives, to possess subsidiary powers which are not expressly provided for in the basic instruments which govern their activities. It is generally accepted that international organizations can exercise such powers, known as 'implied' powers." The Court thus forged deeper down the path on which it first embarked in its advisory opinions in the Reparation for Injuries Suffered in the Service of the United Nations (1949) and Certain Expenses of the United Nations (Article 17, paragraph 2, of the Charter) (1962) cases.

This has been the case to such an extent that the constitutive treaties of some international organizations provide for mechanisms for reform and evolution that do not require the long and costly process, in political and legal terms, of reforming the treaty itself. Such is the case of Article 308 of the Treaty establishing the European Community, when it provides, "If action by the Community should prove necessary to attain, in the course of the operation of the common market, one of the objectives of the Community, and this Treaty has not provided the necessary powers, the Council shall, acting unanimously on a proposal from the Commission and after consulting the European Parliament, take the appropriate measures." Indeed, Article 5.2 of the same Treaty responded to the overly generous interpretations of this precept by introducing the limitation that "[i]n areas which do not fall within its exclusive competence, the Community shall take action, in accordance with the principle of subsidiarity, only if and in so far as the objectives of the proposed 
action cannot be sufficiently achieved by the Member States and can therefore, by reasons of the scale or effects of the proposed action, be better achieved by the Community."

It almost seems like the unvarnished cry of a group of states fearful of a progressive assumption of powers by organizations, in detriment to their sovereign powers, aware that international organizations have become associations of states with a legal status and life of their own that can lead them to use powers beyond those strictly and expressly provided for in their constitutive treaties. They are something more than the sum of the individual wills that establish them, because, as the Court has had occasion to state in two judgments in diametrically different situations - the South-West Africa (Ethiopia v. South Africa; Liberia v. South Africa), Second Phase (1966) and Military and Paramilitary Activities in and against Nicaragua ( 1986$)$ cases - states cannot individually attribute to themselves the competences attributed to an organization as such.

As a result of all the above, international law theoreticians strive to highlight the importance of international organizations today, not only for understanding, but also for the development of international society. There are thus meticulous studies analysing the international organization phenomenon in detail and even differentiating between the types of international organizations, to clarify the capacity of each organizational model to influence the construction of international society. Briefly, a distinction has been made between universal and closed organizations, depending on whether they aim to bring together all existing states in the world or, on the contrary, their appeal is limited to groups of states characterized by their geographical location or their involvement in common ideas or objectives. Likewise, a distinction is drawn between general organizations, whose objectives include the wide range of issues affecting international relations, and particular or specialized ones, which specialize in a specific issue or set of issues, whether economic, military, social or of any other nature. Finally, depending on the powers with which they are endowed, a distinction is also usually drawn between cooperation organizations, whose essential objective is to be a medium or forum for the coordination of state policies and which do not have any real decision-making powers over the states, and integration organizations, which are invested with the necessary powers to implement the policies decided upon in order to achieve their goals.

In accordance with the specific type of organization we are dealing with, one could say that closed organizations (due to the more likely homogeneity of their members), specialized ones (i.e., those whose objectives are limited to specific issues rather than the full spectrum of aspects involved in international relations), and, finally, organizations that integrate the policies of their member states and have decision-making powers over them will be more influential in the construction of international society, more capable and decisive in shaping it.

However, no matter how broad and varied the chromatic ranges of international organizations, it is postulated that all of them, with greater or lesser strength, have made international society the world it is today. These achievements are especially striking given the relative youth of the international organization phenomenon, which did not effectively see the light until the $20^{\text {th }}$ century, notwithstanding some important forerunners in the $19^{\text {th }}$ century, yet has nevertheless experienced levels of development and success that were absolutely unforeseeable just a century ago.

And yet the reason for this may lie in the impression that, in the last two decades of the $20^{\text {th }}$ century, the model has been working differently, and not exactly for the better, suggesting a 
considerable transformation in the roles assigned to organizations as change agents. At the threshold of the $2 \mathrm{I}^{\mathrm{st}}$ century, a certain operation has been undertaken to discredit universal organizations that, moreover, have objectives spanning the full set of factors comprised by international relations. In other words, the adulation of the specific and the near seems to have eroded the prestige of organizations with general objectives and universal membership. Furthermore, one might perhaps point out that international organizations with democratic voting systems are being challenged more than those with weighted voting models or that require the unanimity of their member states to adopt decisions, which should come as no surprise given the aforementioned supposed challenge to state sovereignty.

I believe that, in effect, the democratization of international society peaked in the r 960 s and I 970 s with the international organization phenomenon. In the wake of the decolonization process, the number of states tripled. Nobody disputed that the new states, by virtue of the principle of sovereign equality, would participate in international organizations with equal rights and duties. Thus, the organizations not only welcomed the new states but, driven by the voting rules established in their own constitutive treaties, designed policies tailored to the needs of the states newly come to international society and whose basic problems were unquestionable. To cite just one example, no one was surprised when, on i May 1974, the UN General Assembly adopted Resolutions 3201 and 3202 (S-VI), seeking the establishment of a new international economic order, with even the date on which they were adopted being symbolic. The new international economic order reasonably considered that the world of states was riven by a fundamental gap between developed states and states benevolently referred to as "developing", with the logical consequence that the former should, in the sense of a legal duty, help fund the development of the latter with a contribution equal to, at first, $\mathrm{I} \%$ and, later, $0.7 \%$ of their GDP. This would be done in accordance with the application of strict criteria for repayment of what was owed, on the understanding that the current level of underdevelopment of many states was the result of the exploitation to which they had been subjected under colonialism.

Although at first the developed countries stoically bore the adoption of democratically made decisions at international organizations and the subsequent radicalization of the accusations levied against them for noncompliance with what the majority of states demanded, this permissive policy would come to a dramatic end due to the predominance of liberal ideas in the rg8os, first promoted by Mrs Thatcher and, then, by the Reagan administration. Situations were to be dealt with "one problem at a time, one step at a time, one country at a time", which unquestionably amounted to the affirmation of bilateralist criteria and the abandonment of multilateral forums of which international organizations are the preeminent example. This is basically the process taking place at all universal international organizations and that, in some extreme cases, has led prominent member states to leave certain organizations (e.g. UNESCO, the ILO) or to default on the payment of the organization's mandatory membership dues (e.g. the UN).

The situation has not become widespread due to the existence of a threefold corrective factor. First, when an international organization's core constitutional criteria match the prevailing liberal criteria, and it has established legal mechanisms for peaceful dispute settlement, as in the case of the World Trade Organization, states at the top of the social ladder are not scared by the existence of automatic majorities of the opposing side. Second, when an organization's operating mechanism is not based on the criterion of "one state, one vote", but rather establishes weighted 
voting systems (e.g. the World Bank Group or the International Monetary Fund), the voting majority ensures that the organization's policies will cater to the basic interests of the best positioned minority. Third, in some cases, organizations have established de facto mechanisms to prevent the use of the voting power. This third factor calls for some additional explanation.

In earlier decades, when the voting power of the vast number of states to emerge from the decolonization process was obvious, political and scholarly appeals for reason were often made in the sense of preventing a tyranny of the majority in the adoption of new international instruments. A procedure based on consensus amongst the states was postulated, which was the logical consequence of the gradual and cautious way in which international law had developed: it was a matter of preventing the cord from being drawn so taut it wound up breaking, to which end it was advisable to use consensus-based techniques. Consider, for example, the mechanism for the negotiation and adoption of the 1982 Convention on the Law of the Sea. However, what was conceived of as a system to prevent the tyranny of the majority has given way to a tyranny of the minority, recalcitrant but entrenched in positions of privilege, as would be shown by the requirement to adopt Resolution 48/263, of 28 July 1994, including the Agreement relating to the implementation of Part XI of the United Nations Convention on the Law of the Sea of ro December 1982, which amended the Convention to meet the demands of the more developed states with regard to seabeds and ocean floors. Furthermore, even when the demands of this minority are respected, there is no guarantee that they will ultimately accept the content of the agreement or concession, as evidenced by the fact that, despite the conciliatory effort entailed by the r994 Agreement, the main state behind it, the United States, has yet to ratify the amended Convention.

These factors may show that we are witnessing a major failure of international organizations whereby the only international organizations or bodies of international organizations that can be said to be effective are those that either are not democratic in their decision-making processes, because they have weighted voting, vetoes, or unanimity-based systems, or are highly specialized in terms of the objectives, principles, and powers set out in their constitutive treaties, or are regional or similarly closed in their composition in a way that ensures homogeneity in the conceptions of their members. In other words, we would be witnessing a tendency to reject universalism and a reaffirmation of particularism, a situation that cannot be considered the most progressive for the construction of the $2 \mathrm{I}^{\mathrm{st}}$-century world. One can even look on undaunted as a specialized regional organization, NATO, reformulates its constitutional bases, on the occasion of its fiftieth anniversary, to the point of affirming its ability to act in geographical areas that are not its own and usurping the powers of the United Nations Security Council, as it did in the intervention in Yugoslavia. Likewise, it may seem pathetic that, in his September 1998 report on the organization's work, the current Secretary General of the United Nations, all but armed with resilience, centred much of the organization's success on the reduction of the number of its civil servants to fewer than 9,ooo (recall that the European Communities have more than 3o,ooo) and on the efforts to balance a budget hampered by foot-dragging on the part of the United States in paying its outstanding dues.

\section{(3) The humanization of international law}

Today, nobody disputes that international law has undergone a process of humanization that no one could have predicted just half a century ago. This humanization process can be seen in a 
variety of data. First, there is growing concern both for the fundamental rights and freedoms of individuals considered individually and for the progressive establishment of effective mechanisms to protect those fundamental rights and freedoms and internationally sanction violations thereof, such that states are no longer the exclusive intermediary and guarantor of their realization. Second, this humanization process is no less evident in the emergence and gradual delimitation of the concept of "people" and the establishment of the right of peoples to political self-determination and even to establish themselves as a new state, despite being part of a previously established state. Finally, third, this humanization is also on display in a global conception of what is human that has given rise to the idea of mankind or humankind and its halting enshrinement in texts of a strictly legal nature.

These three facts clearly show that states and international organizations are no longer the exclusive subjects of the international order and, even more importantly, that international law has to be understood based on this plurality of elements. This is true to such an extent that some might see in them the decline of the state, which is insufficient to control them and, even more tellingly, unable to meet their demands. International texts mention each of these things so many times, so expressly, and laying out such precise mechanisms for their fulfilment that any attempt to reflect on the matter is senseless, due to its obviousness. Nevertheless, at the threshold of the $2 \mathrm{I}^{\mathrm{st}}$ century, we may be witnessing the emergence of a set of processes that, without disputing the reality or legal content of these entities, are opening them up to a certain political malleability.

In effect, it is a humanization due to the growing concern for the declaration of the individual rights and freedoms of human persons and, more importantly, for the establishment of effective protection mechanisms. This consideration would almost seem pointless were it not for the fact that barely half a century ago, human rights matters were considered to fall under the internal jurisdiction of states, which international law was not supposed to affect. Although on io December 1948 the United Nations General Assembly did adopt Resolution 2I7(III), containing the Universal Declaration of Human Rights, that declaration cannot be fully understood without reference to the context of the Cold War. Around that time, the United Nations had taken up the Spanish Question and, for the most part, come out in favour of the position that human rights were an internal matter of the Spanish state. So dramatically has the situation changed since then that today no state would dare invoke its domestic jurisdiction to exclude international concern regarding a human rights issue.

The International Covenant on Civil and Political Rights and the International Covenant on Economic, Social and Cultural Rights, both adopted on ig December ig66, are just two of the major legal milestones reached since then. They are joined by such basic instruments today as the Convention on the Elimination of All Forms of Discrimination against Women, of a 8 December 1979, or the Convention on the Rights of the Child, of 6 December I99o, together with many others specifically aimed at protecting groups of people in need of special protection or eradicating loathsome practices such as racial discrimination, slavery or torture, as well as a no lesser number of instruments drawn up in specific regional contexts, such as that of the Council of Europe. All these instruments have moreover been endowed with verification, control, and complaint mechanisms that, with varying degrees of effectiveness, serve to ensure that they are not merely programmatic proclamations, but instruments of effective protection. 
In a two-way operation, in recent times we are witnessing the affirmation of individual criminal responsibility of human persons for the commission of especially heinous international crimes and the stripping away both of any veil of personal immunity exempting individuals from the action of international justice and of the possibility of the all-powerful national interest serving as a protective mantle to insulate people who have individually committed international crimes. In this sense, the 17 July 1998 Statute of the International Criminal Court, which will quite likely be established in the very first years of the $2 \mathrm{~s}^{\text {st }}$ century, is indicative of a key piece of the system, entailing a large step forward in the theoretical conceptions and practices of international law.

There is no need to reiterate that we are dealing with decisive advances in the field of international law that will have to be credited to the $20^{\text {th }}$ century, even though they are establishing themselves as an essential element for understanding the $2 \mathrm{I}^{\mathrm{st}}$, which is nevertheless dawning under the threat of dark clouds that could degenerate into dangerous storms. Without aiming to artificially sustain a debate that has never been artificial, the first such cloud is an excessively lopsided emphasis on civil and political rights, which never results in much, except to the detriment of economic, social, and cultural rights. Ultimately, what really matters for international society and the law that governs it is not which of this set of rights should have primacy - a question that brooks no discussion in any way. Instead, it is the fact that if the pre-eminence tilts towards formal rights and freedoms - which would be logical given the specific weight of Western countries and their individualist tradition - then the debate over the adequacy of third countries' behaviours in relation to the issue of human rights will take place within a canon of legality formed by precisely these types of rights, leading the scale to tip even further away from the others. In other words: the aim is to ensure a form of political construction regardless of the underlying structural differences that any state society faces. As a result, countries must obtain endorsements of their democracies in order to attain international advantages. It may not be too bold to think that the issue of human rights, essentially understood from the perspective of civil and political rights, is today the new dividing line being sought to be established for the classification of states into civilized and uncivilized, with the terrible consequences this had in the $19^{\text {th }}$ century and much of the $20^{\text {th }}$.

The second dark cloud would be the very existence of this dividing line. If the protection of human rights cannot in any way be considered a matter of the internal competence of states, but rather is a matter of legitimate and legal concern for the international community, it would be understandable if, in the event of gross and massive human rights violations occurring anywhere in the world, the international community as a whole or, where appropriate, the states especially concerned invoked a right of intervention to end the anomalous situations, as was indeed invoked - and as occurred - in Somalia and in Yugoslavia. Irrespective of the debatable issues raised by this alleged right, or even duty, to intervene, the fact of the matter is that it would only be being conceived of for civil or political human rights violations, and would be unlikely to be invoked in relation to violations of economic, social, or cultural rights. Insofar as the great challenges of the $2 \mathrm{I}^{\text {st }}$ century may result precisely from the economic collapse of some state societies - and Africa is a serious contender to remain at the top of that noxious ranking - the alleged right of intervention would simply be a tool of political domination rather than a mechanism materially aimed at achieving a higher degree of fulfilment of the aspiration of human rights. 
The humanization of the international order has been equally verifiable in the $20^{\text {th }}$ century in the progressive formulation of the concept of people. Although the Preamble of the Charter of the United Nations does begin "We the peoples of the United Nations", the expression was simply the result of a recognition that peoples were constituted in states and represented by their respective governments, in a virtually irrebuttable presumption, rendering any subsequent reference to the conceptualization of the term "people" a waste of time. However, the Charter contained the seed for what would later be a powerful development. Although it was not intended to end the colonial system in force at the time, Article 73 referred to peoples who had "not yet attained a full measure of self-government", stating that their interests were "paramount", and establishing what, subsequently, as set forth in Resolution I5 14 (XV), of I4 December 1960 , would become the Declaration on the Granting of Independence to Colonial Countries and Peoples, a tool for the illegalization of any vestige of colonialism, albeit with the caveat that, under no circumstances, would the territorial integrity of already established sovereign and independent states be undermined.

In 1970 , as a result of the Declaration on the Principles of International Law concerning Friendly Relations and Co-operation amongst States in accordance with the Charter of the United Nations, contained in Resolution 2625 (XXV), of 24 October I97o, the organization took another step in the delimitation of the meaning of the term "people". It reiterated that the principle of selfdetermination of peoples "shall [not] be construed as authorizing or encouraging any action which would dismember or impair, totally or in part, the territorial integrity [...] of sovereign and independent States conducting themselves in compliance with the principle of equal rights and self-determination of peoples $[\ldots]$ and thus possessed of a government representing the whole people belonging to the territory without distinction as to race, creed or colour."

As small as the caveat was, it was clear that the territorial integrity of states was an ineluctable principle of the international order only as long as no discrimination was established within states in relation to peoples existing in their territory. Otherwise, in a modern version of a minority right, these peoples discriminated against in their own state would have a right to self-determination and to establish themselves as independent states. It is undoubtedly a remarkable advance, as it is the first clear legal case in which the idea of the state is given back seat to another international legal entity. It should even be hailed as a sign of progress in the construction of an international law closer to basic realities and less concerned with safeguarding a state that, in many cases, hinders the realization of human aspirations.

The content of the right of self-determination of peoples, going beyond the strict sphere of decolonization, was certainly progressive, but it was also dangerous, due to the elements of uncertainty that it cast, in particular, the indeterminacy with regard to what constitutes discrimination and, especially, the mechanisms and bodies to be responsible for making that determination. In a decentralized international society, there is a clear possibility that such a right would be recognized individually by third states based on considerations that each one is supposed to pronounce in good faith and that would give rise to obvious political manipulations. Legal reasoning is unlikely to be able to differentiate between the different international positions in cases such as Kosovo or Kurdistan, to cite examples not too far removed in time or geography.

Finally, this humanization was increasingly clear in the emergence of the term "mankind" as an autonomous idea of dubious legal scope. The earliest references were quite vague, such as the one 
contained in the Preamble of the Antarctic Treaty, of I December I959, which states that it is "in the interests of all mankind" that "Antarctica should be used forever exclusively for peaceful purposes". This legal imprecision was maintained in the Treaty on the Principles Governing the Activities of States in the Exploration and Use of Outer Space, including the Moon and Other Celestial Bodies, of 27 January 1967 , Article I of which provides, "The exploration and use of outer space, including the moon and other celestial bodies, shall be carried out for the benefit and in the interests of all countries, irrespective of their degree of economic or scientific development, and shall be the province of all mankind." However, Article 136 of the Jamaica Convention on the Law of the Sea, of Io December 1982 , helped define the concept, referring to the area of the seabed and ocean floor situated beyond national jurisdictions thusly: "The Area and its resources are the common heritage of mankind."

This succession of cases made it possible to affirm, apart from the literature, that mankind was being introduced as a new subject of international law, proposing revolutionary transformations, whether the recognition of mankind's status as a legal subject or the requirement that seabed and ocean-floor resources be exploited directly by an international institution.

However, the turn of the $2 \mathrm{I}^{\mathrm{st}}$ century calls for a rethinking of these conceptions, which seem both idealistic and removed from what states want the reality of international practice to be. In effect, rather than rejecting the legal concept of mankind, which persists in the wording of Article I36, the states have rejected the possibility of an institutionalized exploitation of the seabeds and of a socialization of the possible benefits to be obtained, preferring instead, in consonance with the prevailing economic ideas, to privatize their management and exploitation. The 1982 Convention did not succeed in entering into force until the amendments that the developed states sought to make to it were accepted: on 28 July 1994, the General Assembly adopted Resolution 48/263, which included the Agreement relating to the implementation of Part XI of the United Nations Convention on the Law of the Sea of io December 1982 . Reading it, one might wonder what actually remains of the idea of the Area as the common heritage of mankind or, more specifically, what content the concept of mankind will retain, in the legal sense, beyond that of mere poetic licence that does not in any way diminish the powerful strength of the states, akin to when we refer to a place or a monument as the cultural heritage of humanity.

\section{(B) THE RULES OF INTERNATIONAL LAW}

Strictly speaking, in international law, there are no centralized mechanisms for creating rules; each legal obligation for each state arises, in principle, from its consent, with a dual implication. First, the legal obligations, the rules that bind each state, are the result of that state's consensual acceptance of those rules. On the other hand, international law is not particularly stringent, from a formal point of view, with regard to the requirements and demands this consent must meet; the express or tacit acceptance by a state, its actions, even its lack of action or silence can all be indicative of its acceptance of a legal obligation that will be binding on it in future. Without exaggeration, the will of the states is said to be the only source of international law. In this sense, and only in this sense, international law can be said to be the most democratically developed legal system, since, in principle, no subject of this law can be compelled by a legal rule in whose development or acceptance it did not participate. For others, this surfeit of democratic 
development is the greatest exponent of anarchy but, because of state sovereignty, is also the only way this system has managed to establish itself and offer projects to regulate international society. Second, insofar as state obligations are derived from rules and obligations that the states themselves have expressly or tacitly accepted, the limitations on state powers cannot be presupposed, but rather have to be clearly established by these obligations. As in a blissful Arcadia, a state is quite free to do anything not expressly prohibited by an international obligation in whose creation it has participated, and this maxim has to be understood in the sense that limitations on state powers cannot be assumed.

Obviously, this operating mechanism casts serious doubts on the international system's ability to regulate a progressively interdependent international society whose problems moreover increasingly clearly call for global or collective solutions for which autarkic actions will not suffice. The history and evolution of international law are, in sum, an attempt to progressively develop state obligations for the regulation of the community of problems. With this concern, the sources of international law have undergone significant changes in recent decades, which have already been assessed in their full extent and meaning. These solution mechanisms, which have important pros and cons, merit some attention.

In an international society of juxtaposed states, which was basically the case until the mid-20 ${ }^{\text {th }}$ century, characterized by an excessive atomization of power, the existence of essentially bilateral international relations, and a lack of international organizations that could generally and systematically serve as forums of discussion and consensus-building to solve common problems, international rules and obligations were developed either through bilateral treaties or by the customary procedure, as a result of a practice generally accepted by states as law. In essence, this development mechanism is slow and has proved inefficient for coping with the increased demands of the world of current international relations. Out of their own interest, states had to start using multilateral treaty-based mechanisms by means of which the states as a whole enabled automatic responses to new demands in the life of international relations.

The basic consequence has been that custom, in relation to treaties, has experienced a significant reversal in terms of its importance as a form of creating international law: whereas in the past most international rules were customary, today most rules are treaty-based. The requirements of generality, uniformity, duration of the practice over time, and that it be carried out under the psychological or spiritual requisite of being required by law did not exactly speed its formation. Although some have pointed to the existence of wild or instantaneous customs, i.e. those that can materialize in a short period of time or due to the reiteration of a small number of antecedents, doubts are always cast as to their real level of acceptance or their enforceability for states that did not participate in the process of their development and consolidation.

In the decades immediately following World War II, custom certainly seemed destined to decline for three reasons: first, its inadequacy for facing the new challenges; second, the increasingly vigorous practice of concluding multilateral treaties, some with general normative aspirations; and third, the growing regulatory power of international organizations.

\section{(1) The growth of states' treaty practice}

Solely for illustrative purposes, and with no claim to excessive conclusions, the Secretariat of the League of Nations registered and published 205 volumes of treaties concluded over the period 
from I9I9 to I939. From I945 to today, the Secretariat General of the United Nations has published more than I,200 volumes of treaties concluded since World War II. This is more than a mere quantitative increase in the number of treaties concluded, especially given the proliferation of the number of states in the international community today. A thorough examination of the volumes of both institutions reveals two especially important facts. First, in the period between the two world wars, the overwhelming majority of treaties were bilateral or barely multilateral, reflecting the existence of an atomized international society with a paucity of widespread interstate relations. In contrast, in the United Nations era the percentage of multilateral treaties has grown considerably, suggesting that states are increasingly aware that international issues require - even if they cannot be fully addressed by - the regulation of relations between peer states: many matters that are the subject of treaty-based relations affect all states equally, regardless of their geographical location, geostrategic importance, or specific problems.

The diversification of subjects covered by recorded and published treaties is equally illustrative. In the past, there was an almost limited set of issues that could be the subject of international agreements, restricted to a handful of matters in which it was considered that the power of state sovereignty could not be fully realized without some type of international cooperation. Today, in contrast, one could be forgiven for wondering whether there is a single issue that could be regulated from purely state-based perspectives. The direct consequence is that, whatever field we look at, we would be hard-pressed not to find some type of international regulation, condition, or interest. It is not that there has been some sort of imperialist expansion of international law, which still works based on state sovereignty, but rather states' sovereign needs have compelled them to coordinate their policies through international actions. Whereas once human relations practically ended at a state's borders, today's relational demands cannot be circumscribed to such narrow confines.

It is easy to see how states' growing interdependence requires regulatory means that can only be achieved through agile, rapid, virtually instantaneous procedures. In this regard, the customary procedure, slow to form and reliant on the parsimonious acceptance of states, was frankly inadequate, whilst the myriad forms of treaties can address difficulties and needs as they arise, with no further delay than states' willingness, or lack thereof, to solve them. Treaties, therefore, have proved to be the most suitable, albeit not the only, means of meeting pressing needs.

Moreover, insofar as problems of interdependence not only affect the relations between two states or a small number of states, but also highlight needs affecting all states, bilateral treaty solutions are either a partial response to these problems or refer to problems of interest to only two or a small number of states in particular. Hence, treaties have become more general, preventing partial solutions from simply diverting problems to an increasing number of alternative cracks.

States' certainty in establishing new rules of conduct to tackle the challenges of the present led to an acceleration of the codification process, although it was still a far cry from that which they showed in their own domestic laws throughout the $19{ }^{\text {th }}$ century. As the Charter of the United Nations had already provided for this function of the codification and progressive development of international law, all that remained was to create the body to do it, i.e. the International Law Commission, to witness a show the likes of which had been hitherto virtually unknown in international society. Currently made up of 34 members elected based on their competence in 
international law and representative of the world's various legal and political cultures, the Commission managed to create an extensive body of conventions that codified and, often, developed international law. Important draft articles thus saw the light on matters of diplomatic and consular law, the law of treaties, the succession of states, the law of the sea, non-navigational uses of watercourses, the personal status of natural persons, international criminal law, and jurisdictional immunities of states, to cite just a few prominent examples of the Commission's work. This work was accompanied by states' efforts to develop international law through plenipotentiary conferences on the most diverse and far-flung matters, ranging from space law, to the law of the sea, the legal regime for Antarctica, human rights and a long et cetera.

The legal landscape was so strongly impacted that the literature could not shake off a certain air of optimism, and discussion of cases of the repeal of the relative effect of treaties was increasingly common, that is, the assertion that some treaties, representing the management of common interests of mankind, generated objective effects even for states that were not parties to them, thereby resembling a procedure for creating legal rules that did not require states' consent to be binding on all states in the international community regardless of their position on the matter being regulated by the treaty. The phrase "general normative treaties" was thus coined in the literature, in reference to treaties concerning general rules of international law or referring to matters of general interest to all states.

The essential characteristics of these treaties would be to have been drafted in an almost universal collective environment, by means of consensus-based techniques capable of having certain effects for third parties, as provided for under Article 38 of the Vienna Convention on the Law of Treaties, that is, by the same mechanism through which customary rules become binding on states, and which would even prevent states parties from attaching reservations to them with the aim of excluding or modifying their provisions. It was confidently noted that we were dealing with an authentic mutation of international law whereby it was acquiring a nature not only previously unknown to it but also contrary to the usual bases for its construction, grounded in consensus.

However, this trend has undergone a noticeable change in the last decade, although the first symptoms were registered in the Ig8os. In short, the system for the drafting of general normative treaties, of any codification and progressive development project, requires a formation process potentially involving almost 200 states. Obviously, in such an overwhelmingly collective environment, a text that satisfies each and every desire of each and every state can hardly be sought. Instead, states must be required to show a capacity to bargain and compromise, to cede on state interests, lest the treaty be limited to a list of principles or general and abstract rules entailing no specific legal undertakings. Furthermore, that needs to be done amongst a group of states that are not only heterogeneous in their stances and conceptions, but are also unevenly positioned on the international socio-economic scale, and in which the most disadvantaged states constitute the vast majority. If, as part of the gradual agreement process, the majority rules are to have any weight at all, the greatest demand for compromise will clearly have to be placed on the states in the minority, which are the best positioned on the social scale. From this perspective, it should come as no surprise that Western states have led the pack in rejecting, first, the objectivist aims of general normative treaties and, second, codifying efforts as a whole. The process undergone for the entry into force of the United Nations Convention on the Law of the Sea, concluded in Montego Bay on 
Io December 1982 and which, despite having been renegotiated to accommodate the demands of the United States, as noted earlier, has not yet been ratified by it, is significant. Unfortunately, other aspects of practice would likewise be illustrative of this trend. However, it may suffice to refer to the changing role of the International Law Commission, whose importance in the process of the codification and progressive development of international law was stressed above. Two important changes have taken place in how it works: the first is related to its composition; the second, to the matters it currently deals with.

With regard to the first aspect, states' eagerness to appoint people to the Commission who, regardless of their level of knowledge of the field of international law, have been, or still are, linked to their respective foreign affairs ministries is increasingly clear. Unlike the old lists of Commission members, which featured globally renowned internationalists, today's lists are more likely to include the names of people who have rendered important services to their respective governments. Accordingly, where once the Commission's reports were required reading for any international lawyer, today the approaches they take are more concerned with foreign policy issues, dragged down by an excessive legal realism, and tinged with all the demands of politics. Curiously, after several years of discussions concerning the Statute of the International Criminal Court, the instrument ultimately adopted at the Rome Conference by representatives of the states was less influenced by political considerations than that drawn up by a body composed of jurists of recognized competence who, in theory, are not hampered by - albeit also not unaware of political concerns.

However, with regard to the question of the matters the Commission is currently dealing with - which are, of course, decided by the United Nations General Assembly, although accepting the Commission's own suggestions - and leaving aside those matters it has already been dealing with for years, such as the international responsibility of states, injurious consequences of acts not prohibited by international law, or objective international responsibility, it is doubtful whether matters relating to treaty reservations, the impact of state succession on nationality, unilateral acts, or diplomatic protection are issues in urgent need of codification and progressive development. As for more pressing issues, the Commission's most recent report suggested it was considering dealing with environmental issues. Of course, the Commission will only go where the states want it to.

Even in delicate matters, such as the Commission's current discussion concerning the issue of reservations, in which it would have to reach some sort of legal agreement on whether the ability to attach reservations to general multilateral treaties is unlimited, provided they respect the objects and purposes of the conventions and their reserved provisions, the discussion of who would be responsible for determining a reservation's compatibility with the object and purpose of the convention in question and the legal consequences of a reservation that would not be is showing that the Commission members from Western states hold the more consensus-based positions, the ones more clearly anchored in state voluntarism.

On another level, it might not be an exaggeration to say that we are witnessing a certain slowdown in the codifying process, due to the difficulties involved, although this statement requires some qualification. On the one hand, some areas requiring a codification effort seem to be absent from the states' agenda. Space law, for example, has not undergone significant changes since the I970s; the discussion, especially with regard to geostationary orbits, remote sensing, and 
television broadcasting, has not budged. In other areas on which public opinion has had a greater impact, such as the environment, the Rio and Kyoto Conferences managed to conclude conventions that no one would hesitate to characterize as "soft law", due to the essentially recommendatory nature of their provisions and the lack of means of action and control mechanisms. In fields such as international economic law, the creation of the World Trade Organization has not been accompanied by substantive texts such as those intended in bygone times on economic matters.

Significantly, however, this sluggishness is not found in all geographical areas, pointing to the possible veracity of the aforementioned theses: not only have the codification and progressive development efforts of the Council of Europe, in Spain's most immediate environment, not shown any sign of slowing down, but in recent decades the rate of homogenization has increased, and it has done so despite the difficulty that the massive incorporation of countries from Central and Eastern Europe, which, in practice, has doubled the number of its members, might have entailed.

\section{(2) The emergence of centralized authoritarian rules}

International organizations were conceived as forums for coordinating state policies insofar as they might be of international importance. As such forums for state coordination or cooperation, international organizations were not usually endowed with the power to adopt legal instruments that would be legally binding on states. Instead, the content of their instruments was limited to recommending that states study, in good faith, the possibility of adapting their behaviour to whatever the recommendation requested of them. States fulfilled their international obligation when they considered, in good faith, the possibility of abiding by the recommendation's content. This good faith was to be assumed; states were not even required to justify the outcome of their consideration to the organization. Before sovereign entities, any other aim would have been exorbitant and contrary to the states' intentions in creating international organizations. Nineteenth-century practice, with the primitive administrative unions and many of the powers that international organizations still enjoy today, is based on this precarious attribution of powers to international organizations.

It is not particularly hard to see that this scheme would prove incapable of coping with the complexity of international relations, prompting at least some international organizations to begin to be invested with more binding powers with regard to states. Although still recommendatory in nature, the legal instruments of some international organizations require states to explain the measures adopted in accordance with the recommendation or, at least, to justify why the intended effect of the recommendation could not be achieved. In this highly subtle and seemingly innocent way, states are forced to publicly explain their courses of action, a considerable advance compared with other eras, with regard to the omnipotent state sovereignty. However, in some international organizations, the legal instrument's merely recommendatory nature is illusory: when a state is faced with an instrument of an apparently recommendatory nature, it either strictly complies with it or, in reality, may be left out of the organization's mechanisms and benefits, causing unendurable harm to states that have simply exercised their authority in matters of being bound by the organization's acts. In other organizations, even though no strict principles have been established regarding the legal value of their instruments, the absolutely mandatory nature of their bodies' decisions becomes clear in practice: when a state seeks aid from the International Monetary Fund 
or the International Bank for Reconstruction and Development, the award of that aid is contingent on its adherence to a specific economic policy. Current practice offers enough examples to obviate the need to explore these issues in greater detail. However, the basic general principle is that the legal instruments of international organizations are recommendatory in nature. It is thus neither surprising nor particularly shocking that states are slow to comply with their content, without incurring any sort of international legal responsibility as a result.

Sometimes, however, the organization is vested with more binding powers and may even force a state to achieve a certain outcome by a given deadline, although how to do so is left up to each state. In the field of European Community law, everyone is familiar with the mechanism used in the directives. The procedure is effective insofar as states are bound to be in strict compliance with the directive by an established deadline; otherwise, national judges or the Community bodies themselves will see to its enforcement.

Some organizations, due to the importance of their objectives or the coherence of their members, do not want or cannot afford the possibility of state behaviour that randomly conforms to what the legal instrument requires. For example, if the members of the international community have attributed the primary responsibility for maintaining international peace and security to the Security Council, the Security Council may recommend or decide on the necessary measures to achieve that goal. In the case of a decision, all states are legally bound to comply with its content, lest they incur international responsibility, which can only be excluded by the Security Council itself or on any of the grounds precluding wrongfulness provided for under international law. It is thus starting to become a familiar sight to find binding decisions published in the Official State Gazette with consequences for both public authorities and the people they govern, such as in the case of sanctions adopted against Libya, Iraq, Haiti, or Yugoslavia. The phenomenon is especially familiar in the field of Community law due to the Community regulations, which are directly and immediately binding from the moment they are published, taking precedence over Spain's domestic laws, and whose publication in the Official State Gazette is moreover excluded.

This ability of international organizations to draft legal rules that can become binding for states explains why these rules are said to be centralized and authoritarian, in contradiction of the classical assertion that all international legal obligations are the result or exponent of state consent, given that this consent is not present in the instruments of international organizations. Although these organizations may be composed of states, and it is the states that drive their decision-making, they are nevertheless distinct and separate legal entities, not the mere sum of the member states that make them up.

On the other hand, it might be argued that although this conclusion is true, it should not be exaggerated, given the scant number of organizations that, in accordance with their constitutive treaty, have the ability to generate binding legal instruments; the instruments produced by the overwhelming majority of organizations are of a strictly recommendatory nature. Aside from the fact that when, in purely theoretical terms, reference is made to a given possibility, the number of cases generating binding effects would not change the phenomenon of the emergence of centralized authoritarian rules itself, there is another factor that should be taken into account to calibrate the full potential of international organizations' regulatory power. Indeed, even when an international organization's instruments are merely recommendatory in nature, the reiteration of instruments in the same sense, the widespread support of the member states for their adoption, 
and the clarity of their content can have consequences not initially intended by the constitutive treaty of the organization in question from a formal point of view: the possibility that the content of the instruments ends up being demonstrative of a conviction or opinion of the states as a whole, because what it requests of them is a legal obligation that has obtained its binding force through its transformation into a customary rule of international law, as the International Court of Justice would find in the ig86 judgment we will refer to later.

Even if we preliminarily accept these statements, however, we must not leap to conclusions regarding the importance of this process in the construction and consolidation of international law in recent decades or the immediate future. The world of international organizations is so complex, the types of organizations so varied, it would be illusory to reach conclusions that applied equally to them all. This possibility, in general, will depend on two factors. The first is the degree of homogeneity of the organization in question. The fewer the members an organization has, the greater the chances will be for closer cohesion between them and, thus, for them to reach more intense and specific agreements. In contrast, the broader an organization's membership, the more heterogeneous its members will be, which will lower the chances of cohesion, resulting in the reaching of less narrow and vaguer agreements and thus hindering its chances of affecting the customary process. Likewise, the more specific and concrete an organization's objectives and purposes are, and the more technical its nature, the more likely its instruments are to become customary rules. This stands in contrast to organizations with general and abstract objectives, often far removed from technical issues in an effort to push deeper into the complex world of politics, which are less likely to have a real impact on the customary process.

Second, however, how an international organization makes its decisions also influences the legal significance of its instruments: the more demanding the requirements to consider an instrument adopted, that is, the dearer it is to secure the necessary votes, the more jealous states will be of the value of their position. In contrast, at organizations in which decisions are made by simple majorities, more states will view the establishment of their positions as inconsequential or irrelevant. This is a paradoxical but verifiable statement: organizations with more democratic voting procedures tend to have less influence than organizations that require unanimity, establish a right to veto, or implement weighted voting systems. In these latter organizations, states are more aware of the consequences of their individual actions and weigh the meaning of their vote more carefully.

When these affirmations are taken to their practical conclusions, it is no surprise that NATO will always be able to do more than the United Nations, in their respective fields of action, that the Security Council is more powerful - if not more important - than the General Assembly of that organization, or that the executive powers of the International Monetary Fund or World Bank Group make Unesco or FAO green with envy, regardless of the relative importance of their respective goals. Likewise, it is understandable - if not justifiable - that a significant number of states, including Spain, have, at the threshold of the $2 \mathrm{I}^{\mathrm{st}}$ century, redoubled their commitment to specialized regional organizations with voting procedures in which each state matters even as they flee from or undervalue universal international organizations with indeterminate general purposes and voting procedures that, they claim, give rise to automatic tyrannies of the majority. The importance of this situation is that we may be witnessing the birth of a schism in international law between universalism and particularism, which does not in itself pose an unacceptable challenge 
to the construction of an international order that takes global unity and interdependence into account, but which may lead to levels of struggle, conflict, or confrontation as a result of the imposition of particularism over universalism due to the indisputable fact that the particularist states are the best positioned, in all aspects of international relations, to end up imposing their particularism, as the turn of the century clearly seems to be showing.

\section{(3) The resurrection of custom}

In ig86, the International Court of Justice had to settle a question of profound political and legal significance in the suit brought by Nicaragua against the United States in the Military and Paramilitary Activities in and against Nicaragua case. In addition to the difficulty always involved in deciding on an issue with broad political connotations, the Court could not use the Charter of the United Nations as a regulatory framework because of the conditions of the declaration of recognition of its jurisdiction made by the United States. Whilst Article 2.4 of the Charter of the United Nations leaves no room for doubt as to the absolute prohibition of the use of force or the threat of force in international relations, because the Court could not use it, it had to determine whether this prohibition could be deduced from other rules of international law, such as the instruments of international organizations or the existence of a custom resulting from a practice generally accepted as law. In the first area, the recommendatory nature of the countless instruments of the United Nations General Assembly reiterating the prohibition of the use of force made the possibility of citing them as giving rise to legal obligations for the states dubious. However, the reiteration of the content could be demonstrative of a customary practice. To this end, the Court had to address two crucial questions: first, custom has to be general, uniform, and lasting, and practice seemed to offer enough examples of the use of force in international relations to cast doubt on the generality and uniformity of states' acceptance of the prohibition. The Court brilliantly reasoned that sometimes the violation of a rule does not necessarily entail a challenge to it, but curiously may be indicative of its level of acceptance, as when the states that have used force reiterate the existence of the prohibition even as they claim that the specific case is an exceptional situation allowed under international law or that it does not constitute a use of force prohibited by international law. No state, when using force, defends its right to do so. Instead, they excuse the use based on circumstances that preclude their responsibility in the specific situation, whilst reiterating the validity of the prohibition in general. This would demonstrate that the prohibition is fully valid, even if the scope of its content or its exhaustive nature can be disputed.

However, matters of custom require another element, namely, that states' behaviour be based on the conviction that the behaviour, or the obligation to refrain from it, is required by law and not by customs of another nature. In short, it is the requirement of a legal conviction or opinio juris. International case law has had few occasions to analyse the psychological or spiritual aspect of custom in depth. When it has done so autonomously, it has been possible to perceive a trend that, in the specific cases, states had not acted out of a belief in a legal obligation, but as a result of a custom or courtesy devoid of legal content. Now, however, the Court would have the opportunity to refer to in its entirety, and reaffirm, the psychological or spiritual aspect and to verify that the reiteration of the recommendatory instruments of the General Assembly could demonstrate - as indeed they did - the existence of a legal conviction regarding the prohibition of the use of force. 
It has generally been noted that the Court reiterated its construction regarding the opinio juris from the 1986 judgment in its advisory opinion in 1996 in the Legality of the Threat or Use of Nuclear Weapons case, requested by the United Nations General Assembly. This advisory opinion has been surrounded by deep, often meta-legal debate, as it was unable to conclude definitively whether the use of nuclear weapons in cases in which the very survival of the state that resorted to them in legitimate self-defence was at stake would be unlawful, causing some other legal approaches to lose force. Whilst the Court did reiterate, albeit tenuously, the importance of the opinio juris, it seems that in this case it was difficult to advance any further down the path it had begun in 1986 , precisely in view of the minority, but consistent position of those states that have never renounced the possibility of using nuclear weapons as a last resort in legitimate self-defence. To some extent, we would be dealing with two legal convictions, in seemingly different matters, affecting the outcome of the same question: the legality or illegality, in any case, of the threat or use of nuclear weapons.

With these two cases, legal conviction, as an autonomous element shaping custom, would have emerged considerably reinforced, to the point where, in the event of a contradiction between actual state practice, sometimes in violation of the content of the supposed custom, and the unilateral statements made by states or groups in the sphere of international organizations affirming the validity of the rule despite the contradictions in practice, more importance could be given to the affirmations of validity than to the practice of violations. Consequently, custom would have demonstrated an unprecedented ability to survive, even though everything pointed to its gradual extinction as a mechanism poorly suited to the creation of international law today.

However, this resurrection of custom may be flawed, due to the presence of the two types of elements that must be present in custom, even if one wishes to assign them different weights. First, the importance of the element of legal conviction can be extracted from the unilateral declarations of the states or those made in international organizations. If, as noted earlier, a certain category of states is manifesting a tendency to abandon or relinquish the collective means provided by general universal international organizations in order to seek shelter in the safer world of the homogeneity of specialized regional organizations, it should come as no surprise that this group of states will generate legal convictions in that sphere more aligned with their approaches and needs or, at least, quashing claims of contrary convictions created in the former type of organization.

Second, however, custom is the expression of a practice generally accepted by states as law, which means that divergent practices could also be detected by groups of states, which would denote a deepening of particularism as opposed to universalism insofar as one group of states, because of its higher profile and greater international importance, has a greater capacity to create a practice generally accepted as law, in the absence of opposite or divergent practices. This reasoning is perhaps best illustrated by a pointed example, the content of which I will not go into here: in recent years, references to the existence of a so-called right - some even say duty - of humanitarian intervention in situations of massive human rights violations and the absence or inability of the territorial state to put an end to such regrettable situations have begun to be recurrent. If we were to analyse states' declarations on this matter, we might find vigorous affirmations, timid rejections of such a practice, and fearful silences amongst the group of states that make up the international community as a whole. However, were we to set such declarations aside, so as not to limit ourselves exclusively to the question of the opinio juris, and conduct the 
investigation strictly in the sphere of state practice, we would find that only a small number of states - all from the same geopolitical sphere - are actually able to carry out humanitarian interventions and would thus be drawing the profile of this institution, giving rise to the fear that not everything in their outline would be done for purely altruistic reasons.

In other words, subject to the qualifications of the foregoing considerations, we could be witnessing an interested resurrection of custom at the threshold of the $2 \mathrm{I}^{\mathrm{st}}$ century, with the awareness that, today as in the $19^{\text {th }}$ century, custom is the expression of a practice generally accepted as law by those states that actually have the ability to carry out actions of real international significance.

\section{(4) The hierarchical organization of rules}

When international lawyers speak of the sources of international law, more than using a metaphor about the origin of legal obligations, in reality we are engaging in a certain mimicry of domestic lawyers, who, in speaking of the formal sources of law, refer to the form in which the material sources are expressed, be it popular sovereignty, the laws passed by the legislative branch, the regulatory capacity of the executive branch, or the spontaneous action of the various subjects of law. For international lawyers, the only source of law, in theory, is the will or consent of the states, expressed in a variety of ways, although, as noted, the powerful emergence of international organizations has introduced significant changes in this classical conception. If we really want to teach our students about international legal rules, we should draw on their knowledge of civil law, when they study obligations and contracts, to show them that international rules are equivalent to what is usually studied as obligations in civil law. From this perspective, it would make no sense to try to establish a scale or hierarchy of the various obligations that might stem from different contracts: all of them oblige the contracting parties, who, in the event of a conflict between the various obligations, must decide to comply with some and accept responsibility for the breach of others, all in accordance with the principle of party autonomy enshrined in Article i255 of the Spanish Civil Code.

In international law, at first and from a classical perspective, there could not be a legal hierarchy, but rather simply the assumption by states of a series of obligations, all of which were binding on them with the same weight and force. The situation changed, however, with Article ro3 of the Charter of the United Nations, which provides, "In the event of a conflict between the obligations of the Members of the United Nations under the present Charter and their obligations under any other international agreement, their obligations under the present Charter shall prevail." This primacy of the Charter is nothing more than the result of a specific obligation voluntarily undertaken by the states, making it the exception to the principle of equality of the various legal obligations, but it led to the possibility of theoretically conceiving of the Charter as if it were a constitution, with its rules constituting the canon of legality for any other legal obligations.

The situation of exceptionality underwent an indisputable quantitative change as a result of Articles 53 and 64 of the Vienna Convention on the Law of Treaties of 1969 , according to the first of which, "A treaty is void if, at the time of its conclusion, it conflicts with a peremptory norm of general international law. For the purpose of the present Convention, a peremptory norm of general international law is a norm accepted and recognized by the international community of States as a whole as a norm from which no derogation is permitted and which can be modified 
only by a subsequent norm of general international law having the same character." Article 64 regulates the legal effects of the emergence of a new peremptory norm with regard to existing treaties, with the consequent effect of annulment. Thus, the principle of party autonomy, theretofore unquestioned in international law, was subjected to limits similar to those established in the Spanish Civil Code, when it refers to the law, morality, and good customs as limitations on the autonomy of the parties to a contract.

By that point, this trend seemed unstoppable in international law, evincing characteristics similar to those often pointed to in states' domestic laws, to the extent that, when, in the I970s, the International Law Commission was developing the Draft Articles on State Responsibility, a task it is still working on today, it did not seem like overreach to seek to distinguish between crimes and delicts in international law, as Article ig of the Draft Articles does. An internationally wrongful act constituting a breach of an international obligation, regardless of the subject matter of the obligation breached, would be a delict. In contrast, the breach of an obligation essential for the protection of fundamental interests of the international community as a whole would be an international crime. The article then provides a list of these interests so essential their breach could result in an international crime, as well as examples of such breaches, including aggression, the establishment or maintenance by force of colonial domination, slavery, genocide, and apartheid, or massive pollution of the atmosphere or seas.

With this line of reasoning, not only did international law establish, for the first time, a hierarchical, albeit succinct, order for its rules based on their special importance, but the breach of certain ones could give rise to more dramatic consequences than the mere assumption of responsibility by the offender, giving rise to the possibility of establishing punitive or sanctioning measures depending on the seriousness of the breached obligation.

There can be few doubts that we are dealing with transformations in international law that for some amount to a true mutation of its traditional nature. However, worrying symptoms can be observed in recent practice that may indicate that some of the progress made is being undone. First, whilst NATO's intervention in Yugoslavia was a worrying violation of the provisions of the Charter in matters of maintenance of international peace and security and, especially, the competences of the Security Council in this area that no criterion of legitimacy can obviate, the fact that, on the occasion of its fiftieth anniversary, NATO also proceeded to a sort of re-founding at the 1999 Washington Conference, whereby it openly affirmed the possibility of acting outside or beyond the scope of the Charter of the United Nations, may be even more troubling, as it goes beyond a specific case. It challenges the Charter's constitutional nature, or the supra-legal, almost constitutional nature of the obligations arising thereunder.

Second, although it will not allow us to reach any final conclusions, within the context of the Sixth Committee of the United Nations, tasked with considering legal questions, and as a result of the examination of the International Law Commission's reports on the Draft Articles on State Responsibility, at least two important states, the United States and the United Kingdom, have stated that Draft Article i9, i.e. precisely the article establishing the distinction between crimes and delicts, contaminates the draft articles as a whole and have insinuated the desirability of omitting it, thereby reducing the draft articles to a classical approach to international responsibility. Whilst legal rules and their exact content can of course provide certainty and security for relations, they can also be viewed as rigid corsets impeding naturalness and freedom of movement: both 
sentiments are real reflections; each subject will accentuate one or the other for merely subjective reasons.

\section{(C) THE FUNCTIONS OF INTERNATIONAL LAW}

International law was originally an essentially jurisdictional law, that is, a legal system primarily concerned with the distribution and regulation of powers amongst its subjects, which were states and, thus, spatially configured. Broadly speaking, international law distinguished between states' internal powers and their international relations. International society was conceived of as a system of opposing states, and its legal system simply sought to regulate foreign relations. What happened within each state's borders was considered a matter of domestic or internal jurisdiction. Hence, international law confined itself to regulating the limits of states' powers abroad in order to prevent overlaps or clashes from becoming sources of international conflict. Needless to say, this was possible due to the conception of international society as a society of juxtaposition, equivalent to the idea that states were autarkic systems that only occasionally needed external action.

To the extent that there was a turning point where states increasingly needed to pursue foreign action to achieve their own national goals, there were two possible solutions. The first was to accentuate the juxtaposition of states, underscoring the clashes and confrontations between them and increasing the level of violence in international society, which has certainly happened over long periods in the history of international society. The second was to endeavour to increase the levels of cooperation between states, to make coexistence between them more bearable, and even enable some degree of peaceful coexistence amongst them. State cooperation did not eliminate the levels of juxtaposition absolutely, but it did tend to identify planes in which cooperation was possible and where juxtaposition was inevitable.

Each of these types of international society has a different form of constructing and conceiving of international law. In an international society of juxtaposition, legal rules are of a jurisdictional nature and tend to avoid external friction, whilst in a society of cooperation, even interested cooperation, legal rules are of an attributionist nature and tend to promote rules of conduct that ultimately involve limiting powers that, in principle, correspond to states by virtue of their sovereignty. The more advanced the areas of cooperation, the more evolved the legal rules for them must be and, thus, the more restrictive the possibilities for the sovereign behaviour of states.

This evolution explains why international law has seen a geometric growth of its rules, not so much in terms of the spatial areas with which it is concerned, but of the matters to be regulated. In the first regard, it is enough to cite the example of the progressive regulation of new spaces, such as outer space, the polar circles, or seabeds and ocean floors. Indeed, in the past, had the exploration and exploitation of these spaces been possible, the solution would have been a race for their control, with the consequent invocation of discovery, effective occupation, and intention as the decisive elements for the subsequent exercise of sovereign powers, as happened so many other times in the past with the discovery of new lands. In a non-interdependent international society, these races to conquer new territorial spaces would undoubtedly have resulted in bitter conflicts between states, the costs of which would possibly have outweighed the benefits to be obtained; hence, the cooperative regulation process witnessed in relation to these new realities today. 
However, in the second regard, it is not just a question of new spaces, but also new subject matters. On the one hand, there are problems that cannot be solved through the adoption of unilateral state policy measures. One need only look to the still recent and growing concern for the environment: if air is indivisible and threats to the environment are global, for solutions to be effective, they must necessarily be global and multilateral. Second, if a planetary conception of the human is beginning to emerge in the current global village, problems related to poverty, hunger, or human rights cannot be understood and solved from a hermetic perspective of state sovereignties, which, at most, can hope to clean and keep their own house in order. It is thus necessary for new legal rules to try to regulate the new demands of international society.

Hence, we are witnessing an unparalleled growth in international legal rules, not as a result of any sort of voluntarism, but as a conclusion or solution for new goals and new needs. Were we to compare the content of the old compendia of international law with the current ones, we would clearly see that jurisdictional conceptions have given way to - albeit without being entirely replaced by - attributionist ones, to protect interests and needs shared by all states. This is surely the current greatness of contemporary international law and what makes it quantitatively and qualitatively different from that of bygone eras.

This evolution is important, from both the point of view of international law and the point of view of states' domestic laws, insofar as the increase in international concern entails the expansion of domestic systems to keep up with the new developments. For example, today no one doubts that growing international concerns for the environment have driven this area of the law in the various domestic legal systems, even if it has developed differently, albeit with common basic elements, in each one. Likewise, and subject to the expression of each state's unique perspective, the regulation of human rights has seen exponential growth that would have been unthinkable until recently, with basic elements of assimilation and harmonization.

From this vantage point, assertions to the effect that domestic legal systems will someday be to international law what certain regional legal systems in Spain are to common law are understandable, although certainly still quite illusory. This exaggeration is no doubt due to the level of precariousness with which international law is still developing, in which the notes of juxtaposition and cooperation are not easily replaceable with that of the subordination of state interests to the achievement of common goals and interests, as is already beginning to happen in regional international societies, and as is clearly on display in the integration process of the Members States of the European Communities.

But from another perspective, it is real: international rules are achieving levels of harmonization of state legal conceptions in more and more areas. Of course, herein lies the first misfortune of international law: when international rules achieve their objective of permeating the internal conceptions of states and systematic and widespread compliance with them occurs, the domestic laws lose sight of their international origin, whilst the international system sets out to conquer new fields and spaces in which to achieve harmonization. Hence, the permanent sensation of international law as an incomplete, unfinished, frustrated, or unfulfilled system.

Throughout this process, and in the material content of the different regulations, the existence of contradictory national interests is clear. This works against the possibility of faster, more complete regulatory developments, even if it fails to spark outrage since it is the constitutional basis of operation of the international system. Sometimes, however, an excessive prioritization of 
state interests by those that already have a highly privileged position in international society is incomprehensible, as with the opposition of a prominent group of states to ratifying the United Nations Convention on the Law of the Sea unless it was reformed to ensure the increase in privileged positions that this large number of states already enjoyed.

What might cast serious doubts on the soundness of future developments is the fact that the substantive evolutions undergone have occurred because of the unprecedented impetus of the group of states that lead international society. In other words, the idea that major developments are achieved thanks to the interest of that select group of states, which obviously, due to their greater specific weight and considerable international influence, choose the matters that, in their view, require more and faster development. In contrast, in those areas of the system in which they feel more favoured and better equipped, development is slower and, in some cases, virtually nonexistent. The entire area of the right to development and related matters, such as technology transfer or sharing in the benefits of development, suffers from a lack of legal regulation that seriously hampers the possibilities of peaceful co-existence between states in the $2 \mathrm{I}^{\mathrm{st}}$ century and afflicts the international community, obliging it to live at levels of mere co-existence instead. It is precisely in these matters where a transformation in the functions of international law is most urgent and important, and yet it is in them where changes in the functions of the system are slowest, if they occur at all.

\section{(D) THE APPLICATION OF INTERNATIONAL LAW}

If we previously pointed to the quantitative and qualitative expansion of international law and the overcoming of jurisdictional criteria as what makes contemporary international law great, and to the perception of international law as an incomplete, unfinished, frustrated, or unfilled system as its first misfortune, we can now point to what may be the true great misfortune of international law: the conception of this system as the one for regulating states' foreign relations and encouraging the achievement of common goals and interests by means of permeating domestic legal conceptions. Ultimately, it is a system that drives, rather than deciding or controlling, the levels of compliance with its content, which remain in the hands of states' foreign policy action or of the domestic legal systems themselves. Not in vain are the states themselves responsible for verifying compliance with international rules. The paradox, the great misfortune, of international law is that it is deemed ineffective or incapable for what is actually the ineffectiveness or incapability of the political will of the states or their own domestic legal systems.

The most damaging part is that this accusation is made against a system that is not endowed because the states have not wished to endow it - with real capacity to verify the levels of compliance with its rules and sanction any breaches accordingly. It is unacceptable and immoral to hope, as Ortega y Gasset said referring to international law, that things be magically done, without preparing the necessary means to achieve them. And the means for achieving international legal objectives fall within the scope of state powers.

Indeed, in international law the state is not only the primary and basic subject of the system, as well as the essential basis, via its consent, for the creation of legal rules, but also the party tasked with verifying, monitoring, and sanctioning in case of violation of its provisions, regardless of who breaches them. In the event of a specific legal violation, it is the affected state itself that, in 
principle, is called upon to establish the means to achieve the end of the violation, secure guarantees that it will not happen again, and, where applicable, ensure due satisfaction or compensation for the damage caused. The procedure for this is recourse to direct diplomatic negotiations with the party responsible for the violation or the application of retaliation or reprisal measures, excluding the use of force.

Only as a distant second option can centralized institutionalized means be used to achieve these goals, due to the essentially decentralized nature of the international community. These centralized means are usually provided for by international organizations and, as in many other aspects, the ability of such organizations to meet this requirement will depend on the homogeneity of their members and the specificity of their functions. Furthermore, in international society there are no jurisdictional mechanisms for settling disputes. Instead, international courts may have jurisdiction to settle them, in general, based on the consent given by the states to that end.

The only impression that international society can thus give is that of a loosely structured, disorganized society, which is powerfully striking in a context of historical circumstances in which states' interdependence requires more fluid procedures for verifying compliance with international obligations. Increasingly aware of this need, states have proven willing to establish control mechanisms in general, albeit consistently seeking to prevent them from being applicable to them in particular.

In any case, it is more and more common for international conventions to establish some type of monitoring body to ensure compliance with obligations, of a highly diverse political or legal nature. In some cases, states have a general duty to report to these bodies on the measures they have taken to effectively fulfil their obligations, which may prompt the body to request subsequent clarifications and, in some cases, make recommendations in a positive or negative sense. In others, the bodies may be competent to hear claims or complaints for non-compliance brought by other states, or even private individuals or groups of individuals, with the responsible body being able to make recommendations to the state in breach. On few occasions does the body's ability go beyond these possibilities, except in exceptional situations, such as the powers of the United Nations Security Council when, acting under Chapter VII of the Charter, it deems that a threat to the peace, a breach of the peace, or an act of aggression has occurred.

Only very rarely can international society be said to have jurisdictional mechanisms whereby, as in domestic legal systems, independent, previously established judicial bodies have the power, through a final judgment, to declare existing law and enforce it against a state. However, the situation seems to be experiencing significant levels of transformation in modern international law, although these transformations have both pros and cons.

Indeed, some treaties establish judicial bodies with jurisdiction to verify compliance by states simply because a state is party to the treaty in question. This is the case, for example, of the Court of Justice of the European Communities in relation to the constitutive treaties of the three European Communities or certain specific aspects of the Treaty on European Union. The European Court of Human Rights has likewise had this capacity in relation to the states parties to the European Convention of Human Rights and Fundamental Freedoms of rg5o since the entry into force, on r November 1998 , of Protocol in to that Convention. Finally, it is the situation that will arise once the Statute of the International Criminal Court, signed in Rome on 17 July 1998 , comes into force, as is expected to happen in the next few years. Somewhere in between would be 
the International Tribunal for the Law of the Sea, established under the Montego Bay Convention, of 1982 , which, although it does provide that the states parties to the Convention are, in principle, bound by the court's case law, also allows them to exclude its jurisdiction in general or in relation to specific matters, even when they remain bound by a conciliation procedure whose result, in contrast, is not so legally binding.

The judicial body par excellence is the International Court of Justice, but this judicial body only has jurisdiction in relation to those disputes that states refer to it by agreement in the event of a dispute, when the Court's jurisdiction was established under a bilateral or multilateral treaty, either over the specific subject matter addressed by the treaty or, in general, when the treaty establishes general mechanisms for the peaceful settlement of disputes. The other alternative system, which would bring the Court closer to a truly jurisdictional function, is the mechanism provided for under Article 36 of the Charter of the United Nations, when states voluntarily accept the Court's jurisdiction to hear disputes that may arise, in relation to one or more other states that have also voluntarily accepted the Court's jurisdiction under similar conditions.

This mechanism, the closest to what should be a requirement of international society, nevertheless has some invidious aspects. First, acceptance of the Court's jurisdiction is not unconditional, but rather can be subject to temporary or substantive conditions, excluding its jurisdiction for certain types of cases or matters. Second, to date, fifty years after the Court was created, a total of 63 states have accepted its jurisdiction, equivalent to only about a third of the members of international society (I9 from the group of Western European and other states; 6 Central and Eastern European ones; 13 Latin American ones; 18 African ones; and 7 Asian ones). Third, of the five great powers, only one, the United Kingdom, currently accepts the Court's jurisdiction. Furthermore, whilst the Russian Federation and China have never accepted it, France and the United States withdrew their acceptance of its jurisdiction after suffering respective defeats in judgments delivered by the Court: France, in the Nuclear Tests case, in 1974; and the United States, as a result of the suit brought by Nicaragua, in the Military and Paramilitary Activities in and against Nicaragua case, from I984. To put it in a depersonalized way, this would suggest that the political interests of the great powers are unwilling to submit to jurisdictional pronouncements.

In any case, the scholarly literature approaches the recent proliferation of judicial bodies outlined earlier as a turning factor that may indicate a significant transformation in the international law of the near future, a conclusion with which I would agree to the extent that it ends up familiarizing states with jurisdictional procedures, even if sectoral ones. However, it is worth highlighting some aspects of this transformation that may not be positive. First, of the five existing courts (including the International Criminal Court), two - the CJEU and the ECHR have limited jurisdiction, as their geographic scope is limited to Europe, suggesting that we are once again witnessing a process of regionalization or particularism in the face of the needs of universalism. Meanwhile, four are specialized and have limited jurisdiction in accordance with the objectives established by their constitutive treaties; only the International Court of Justice would have jurisdiction to hear any matter related to international law. Thus, we could also be witnessing a process of sectorization of international law that could ultimately mean that, whilst states are willing to accept legal rules of the game subject to judicial control for some matters, in the rest they prefer a freer game for political considerations. Additionally, and rejecting or setting aside the aforementioned objection, we could be witnessing a process of sectoral constructions of 
international law that would result in contradictions between the various sectors and with international law as a system, which, in turn, could cause significant cracks in the global construction of international law with unpredictable results.

Finally, it seems pertinent to refer briefly to certain extraterritorial trends that states are experiencing in the decentralized search for solutions to the problems of application of international law, which can be grouped in two specific mechanisms. First, some states are exhibiting a tendency to enact domestic laws intended to force third states to follow a certain line of conduct, which they consider to be required by international law, by means of sanctions, embargoes, and similar mechanisms. In principle, this aim can be considered in accordance with international law, provided it does not contravene international obligations of the state choosing this course of action, especially when it is manifested in areas in which each state is free to negotiate or not negotiate, to confer or not confer certain rights to third states. However, these laws would be contrary to international law should they aim to establish obligations that force third states to follow the same policy in relation to the state they are crafted against, as in that case they would contain a claim to an extraterritorial effect that would infringe on the freedom to conduct relations with third states. The popularly known Helms-Burton Act would be a prime example of this trend. Its contradiction with international law is apparent in that, through it, the United States aims to erect itself as the controller of the application of rules of international law that it has announced, by any other state in the international community, despite the decentralized and unilateral nature that constitutes the basis for operation of the international legal system in this field, except as provided by the existing international institutions with jurisdiction to do so.

Likewise, second, there is an increasingly clear trend by some legal systems, including Spain's, to establish themselves as international judicial bodies with jurisdiction to try violations of international law, beyond the requirements established in international conventions themselves, regardless of where the crime was committed and of how it affected the state in whose name the judicial authority is acting. If states are reluctant to accept the jurisdiction of international criminal courts created for the specific purpose of sanctioning the conducts of individuals who have committed ominous internationally recognized crimes, as the difficult process of drafting the Statutes of the International Criminal Court and the slow mechanism for its entry into force have shown, then certainly no state can claim, beyond the specific rights and duties established under international treaties, to be an international judge with jurisdiction to hear cases on matters occurring anywhere in the world.

These are simply specific examples of a trend that a prominent group of states is imposing on international society, whereby they offer themselves as guarantors of legal obligations that may not even be binding on some of the states being required to meet them. Witness the case of the pressure for some states to comply with the provisions of the Nuclear Non-Proliferation Treaty, of I July I968, still in force through the extension agreed on I2 May I995, to which they are not parties, or to adopt unilateral coercive measures, as was done against Sudan in relation to an alleged violation of the Convention on the Prohibition of the Development, Production, Stockpiling and Use of Chemical Weapons and on their Destruction, of 13 January I993, which was not even binding on it at the time the events occurred. 
The placid breaking of the waves on the beach on a calm day fosters the fantasy that each wave is unique and unrepeatable and that there will never be another one exactly like it, no matter how many times the surf comes crashing in. We can play with them and with their illusion, but it takes no effort to accept that, in reality, it is always the same sea. In the social sciences, we sometimes also think that what we are living through is one of a kind and, indeed, strictly speaking, it is, creating the impression that it is difficult to classify and impossible to understand. The old repeats, whilst the new is mixed, preventing full knowledge of either one: every generation has always lived under the impression that its experiences are unique and unrepeatable, making it impossible to understand them until the cold judge of time offers distance, perspective, and dispassion.

At the start of this lecture, I promised to offer some reflections based on perplexity, the perplexity, no doubt, of one who sees processes he cannot fully understand or classify. Reflection ultimately allows us to express our doubts aloud, but it would be pretentious to reach for conclusions beyond one's own inability to integrate the content of those reflections in an orderly fashion. Furthermore, doubts are simply exponents of the value scheme and anxieties of the person who voices them, so that, at least in the social sciences, their subjective content, their anchoring in values and ideologies, is unavoidable. It is with these elements that I am going to dare to conclude my reflections on the state of international law at the threshold of the $2 \mathrm{I}^{\text {st }}$ century. In any case, I am not going to offer a select bouquet of the doubts that international law poses to me in light of the new century, as if the critical capacity of the recipient of these reflections needed hurried final summaries from me. Instead, I will try to conclude with some ideas that might synthesize the concerns that the current development of international law reflects.

We seem to be faced with a tendency to develop a particularist international law, overly attentive to the needs and demands of the few and less sensitive to the preoccupations and concerns of the many. It is a homogeneous international law at the regional or particular level that, however, is offered or imposed as a solution at the universal level, where it is dubiously suited to the basic structural problems of contemporary international society.

Perhaps we are witnessing an international law that is losing the challenge of solidarity only to accentuate unacceptable inequalities, inequalities whose very existence is denied or deemed solvable through the adoption of formulas that, in the first world, yielded obvious and optimal results. In international society, as in domestic societies, a sort of groupthink seems to have taken hold and established itself as a panacea for any tension.

One could be forgiven for thinking that current international law is experiencing a kind of return to the future, to a igth-century, non-universal international society, in which states were classified as civilized, semi-civilized, or barbaric, and only those in the first category were entrusted with the sacred civilizing mission based on guidelines only they were in a position to suggest.

It is not a pessimistic view, but a matter of registering factors, whether positive or negative: the intellectual's mission should not be to offer a reassuring vision, but to shine a spotlight on the elements that threaten the future, not because they are the only ones, but because they are the ones that can most affect the future of the coming generations. Regression, stagnation, or historical progress are not the result of inexorable physical laws, but the product of human capabilities and, above all, human will. There is nothing written, except the page we write each day. 